\title{
Illusions and Realities of Soviet Belarusisation
}

\author{
BY \\ LIZAVETA KASMACH*
}

\begin{abstract}
Marková, Alena.
Sovětská bělorusizace jako cesta k národu. Iluze nebo reality? (Soviet Belarusisation as a Path to Nationhood. Illusions or Reality?), Nakladatelství Lidové Noviny: Praha, 2012, 264 pp.
\end{abstract}

$269 \mathrm{Kč}$

ISBN: 9788074222306.

Should we regard the Soviet Belarusisation policy during the 1920s as a realistic way to build a modern nation from above or was it only an illusion? A thoroughly researched and detailed case-study of early Soviet nationality policies by Alena Marková reveals the mechanisms of the state-sponsored national development program, with attention given both to the immediate process of its implementation and its long-term implications. This allows her to trace the current problematic character of Belarusian national identity and persisting indifference to nationalism back to the origins of contemporary Belarusian society, laid down in the early Byelorussian Soviet Socialist Republic (BSSR).

This book explores the peculiarities of the Belarusisation policy in the 1920s by analyzing the challenges of nation-building from above in a largely pre-modern society where local and religious identities dominated, while language as a national identity marker remained weak. The Bolshevik regime acted as a modernizing force and attempted to accelerate the process of national development. Belarusisation serves as an example of this artificially implemented campaign. Marková argues that eventually the Soviet policy of Belarusisation failed to establish a strong link between the Belarusian language and national identity, due to its brevity and inconsistent character. Despite the fact that the number of Belarusian schools increased and illiteracy diminished, in the long-term the Belarusian language remained dependent on Soviet affirmative action and did not turn into a crucial factor in the process of national identity formation.

* Lizaveta Kasmach is a PhD candidate at the University of Alberta, Canada. 
The study is organised chronologically, covering the entire period of the 1920s in Soviet Belarus in eight chapters. Situated within the broad context of Soviet history, it focuses in particular on the time period 1924 - 1929 in the newly created BSSR. Soviet Belarus at first included six districts of the former Minsk province in July 1920 and later the territories of contemporary eastern Belarus added between 1924 and 1926. Key chapters deal with Belarusisation policies of the republican government and in the sphere of education. The latter includes a survey of the situation in primary schools, professional schools, and higher institutions of learning, as well as an analysis of the ideological foundations of the textbooks that were designed to support this new policy. The book investigates the origins of Belarusisation, its components, development and results, while taking into account both its positive and negative effects. On another level of analysis, this work also follows the immediate course of Belarusisation at the local level, depicting reactions of different population groups, national elites, high-level party members, and officials. Noting the differences between the Belarusian historiographical tradition, which tends to pay more attention exclusively to the language issues, and Western scholars, who prefer to prioritize korenizatsia over linguistic policy, Marková generally chooses to treat Belarusisation as a specific phenomenon in Belarusian nation-building. She understands it as a process of cultural and linguistic consolidation of the nation, in which korenizatsia constituted an integral element contributing to the creation of national intellectual and ruling elites (p. 24).

Belarusian Soviet society in the 1920 s had an uneven social structure. The majority of ethnic Belarusians populated the rural areas, while Russians and Jews dominated the urban environment. Marková emphasizes that this situation resulted in the persistent low social status of the Belarusian language, which continued to be a serious obstacle to all Belarusisation efforts. One of its leading proponents, Usevalad Ihnatoŭski, remarked that even peasants often spoke out against Belarusisation in Belarusian. They pointed out that the ruling elites did not use the language, hence it appeared to be unpractical for ordinary people too (p. 40). On the other hand, the example of the director of the Printing Department in the Council of People's Economy, a certain Strongin, illustrates the typical reasoning of officials. He claimed that no one wanted to read Belarusian books, therefore it made no sense to print them. This led to prolonged conflict between the state printing facilities and the People's Commissariat of Education, during which the latter eventually decided to print 138,500 copies of textbooks in Belarusian in Germany (p. 105).

In 1924 Belarusian became a priority language in the BSSR, receiving full official support. Marková notes the obvious paradox of this situation. Agitation campaigns for the use of Belarusian took place in Belarusian schools for Belarusian citizens. The new policy could soon claim some successes, since the numbers 
of Belarusian books, translations and newspapers were steadily growing, and peasants started agreeing to send their children to Belarusian schools. Children adjusted very quickly and demonstrated rapid progress having their mother tongue as the language of instruction. However, these initial positive effects have to be viewed critically, since Belarusisation from above still had a formal character and implementation standards remained low. 95\% of the first graduates from the Pedagogical Faculty of the Belarusian State University could not demonstrate sufficient knowledge of Belarusian (p. 78). Belarusisation proved to be more successful in rural areas where the language needed little encouragement, while the cities, which still retained their non-Belarusian ethnic composition, displayed opposition to the new measures (pp. 64-70).

An analysis of contemporary textbooks from the period allows Marková to conclude that Belarusisation possessed another paradoxical feature. It was national not only in form, but also in content. The Soviet state still lacked a 'proletarian' intelligentsia that would have been able to promote Soviet values exclusively. Instead it had to rely on representatives of the national 'bourgeois' intelligentsia, as the chief agents of the new policy (p. 44). Therefore, it is not surprising that the new history textbooks created a nationally oriented narrative, which fully contradicted the idea of Soviet centralisation. This development served later as a pretext for the Stalinist repressions and the re-emphasis of class struggle (p. 125).

In contrast to schooling, the Belarusisation of governing institutions had a formal character. While Belarusian enjoyed the status of official language of correspondence, Russian still dominated in the everyday communication of the bureaucracy. Officials in the communist party distrusted the activities of a national intelligentsia who wholeheartedly supported Belarusisation. Moreover, the national composition of the party, (where ethnic Belarusians never composed a majority), suggested that it would not react favourably to 'local nationalism' (p. 133). Marková notes that general statements about the overall successes of Belarusisation in this sphere are too optimistic, pointing out that often historians reached such conclusions only using official party documentation. In order to have an adequate image of the implementation of Belarusisation, she chooses as well to look at instances of resistance among ordinary employees and workers to the new policy. Marková argues that the rapid return of the Russian language to public use during the post-Belarusisation period confirms the incomplete and superficial character of Belarusisation (pp.152-53).

The rapid transition to modernity did not leave the peasantry time to develop a strong identity of its own, based on language and culture. Belarusian identity still only had symbolical value for a small layer of the intelligentsia. Marková compares this situation to that of a diver 'coming to the surface without decompression' (pp. 
182-83). The short span of Belarusisation and its weak basis, with devoted support of a small group of national elites on the one hand, and popular indifference or passivity on the other, did not allow it to make a significant impact. While it appeared quantitatively successful (for instance, the number of schools, book titles, newspapers), qualitatively it only started to unfold and did not lead to formation of a stable national identity.

This monograph uses a variety of sources, including a wide selection of unpublished archival materials, reflecting the Soviet nation-building programme from above in all its contradictions and ambiguities. Despite the fact that the book focuses specifically on Belarusisation, an additional view on the treatment of Poles, Jews and Russians in the BSSR and public reactions to the support of minorities could have complemented the picture of the nationalities policy in the BSSR during the 1920s. At the same time this study could have benefited from a slightly different structure. Some of the theoretical concepts could be moved from the concluding part to the introduction, thus providing readers with the necessary analytical framework. Apart from these minor caveats, Alena Marková's study represents a valuable addition to the Belarusian historiography of the 1920s, offering critical insights, convincing examples and well-informed conclusions. 